\title{
WIND ENERGY CONVERSION SYSTEM USING MAXIMUM POWER POINT TRACKING TECHNIQUE - A COMPREHENSIVE SURVEY
}

UDC: 621.548

Review

https://doi.org/10.18485/aeletters.2021.6.4.2

\author{
Mohsin Ali Koondhar ${ }^{1 *}$, Majid Ali ${ }^{2}$, Muhammad Usman Keerio ${ }^{1}$, Abdul Khalique Junejo ${ }^{1}$, Imtiaz \\ Ali Laghari ${ }^{3}$, Sadullah Chandio ${ }^{1}$ \\ ${ }^{1}$ Department of Electrical Engineering, Quaid-e-Awam University of Engineering, Science and Technology \\ Nawabshah, Sindh Pakistan \\ ${ }^{2}$ Member IEEE Department of Electrical Engineering, The University of Lahore, Pakistan \\ ${ }^{3}$ Department of Electrical Engineering, Quaid-e-Awam University of Engineering, Science and Technology \\ Larkana Campus, Sindh Pakistan
}

\begin{abstract}
:
Over the past decade, wind power generation (WPG) has focused on energy generation, and much research is being done on renewable energy (RE), especially wind energy (WE). WE guarantee environmentally friendly power generation and help to meet national energy needs due to the declining trend of renewable resources. In this article, various Maximum Power Point Tracking (MPPT) techniques proposed for wind energy conversion system (WECS) modeling control management strategies and efficient wind power generation (WPG) from available sources have been discussed. In addition, a comparative survey of various familiar soft methods is accorded for an easy power system with the wind. At last, a cost-effective investigation arrived for MPPT techniques found on (a) Saving of energy, (b) period of profit, (c) generated income, (d) cost, (e) capacity utilization aspect, and (f) solidity.
\end{abstract}

\section{ARTICLE HISTORY}

Received: 16.08.2021.

Accepted: 06.09.2021.

Available: 31.12.2021.

\section{KEYWORDS}

Wind Turbine, Wind Energy, WECS, MPPT, Renewable

Energy, PMSG.

\section{INTRODUCTION}

The term "renewable energy" means energy from a variety of sources [1]. They are all based on self-renewable energy sources such as sunlight, wind, flowing water, the earth's internal warmth, and energy crops, and biomass from agricultural, industrial, and municipal waste. These sources can be used to generate electricity for all sectors of the economy, fuel for transportation and heating for buildings, and industrial processes [2].

WE as one of the RE is an interesting method of generating new electricity. In recent times, especially in the last decade or so, farmyard farming has grown and prospered. According to the Global Wind Energy Council by the end of 2017, the world's wind power projects reached around $999 \mathrm{GW}$, an increase of $21.55 \%$ over 2011. In addition, the number of wind turbines (WT) built offshore will harvest large wind resources more efficiently. Offshore wind power reached a historic record in 2017 with 4,334 MW of new installations and its combined output was $18,814 \mathrm{MW}[3,4]$.

Wind power systems have become the most RE source in the last decade due to degradation from conventional energy sources, high costs, and potential for environmental impact. WE is an environmentally friendly and renewable source. Thus, wind power generation systems could be one of the potential alternative energy sources of the future [5-7].

Although these benefits are known to be environmentally friendly and renewable, wind and PV sources can change the wind and there is a risk of uncertainty caused by solar rays, resulting in variable output forces. Large WT can cause the following problems in the power grid:

- Unstable grid frequency,

- The voltage glows in the power grid bus, 
- Instability in the network for loads sensitive to voltage fluctuations [8-10].

Recently, air pollution caused by power plants using fossil fuels such as carbon dioxide, nitrogen oxides, and sulfur dioxide has caused serious environmental problems [11,12]. Pollution seed rainfall and global warming are considered to be the major causes of environmental pollution $[13,14]$. In the USA, nonrenewable fuel source power generating develops release about $2.2 \mathrm{bn}$ tons of $\mathrm{CO}_{2}$ yearly [15]. These problems are facing governments and other agencies around the world to aim to increase the use of $R E$ in power generation. For example, China aims to generate more than $15 \%$ of its overall electricity from sustainable energy (SE) by 2020, including 0.42 TW of hydropower, 0.05 TW of solar, 0.2 TW of wind, and 0.03 TW of biomass. As presented in Fig.1, some countries have unlike targets in the upcoming to increase power consumption from renewable energy sources (RES). The plant is critical to achieving the huge increase in global energy needs while reducing pollution.

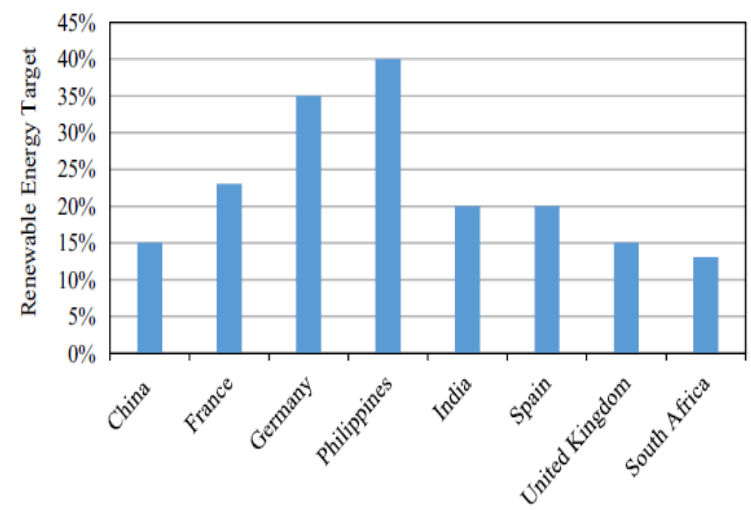

Fig.1. For 2020 SE targets of countries [16]

RE applications have potentially become the agenda of the Hong Kong government in recent years. Wind power is one of the RE Sources for this location due to strong winds over Hong Kong Island and the surrounding islands of the Kowloon Peninsula. According to weather data reported by the Hong Kong observatory, Waglan Island has an average annual wind speed of $6.92 \mathrm{~m} / \mathrm{s}$. it is 26.3 meters above the ground and 82 meters above sea level. The average wind speed is too high for wind power applications $[17,18]$.

The most frequently used wind generator (WG) control systems [19-22] are shown in Fig.2. This architecture relies on faster functions to obtain the best WG performance. These functions are generally stored in the memory of the microcontroller. Measure the speed of WG and to calculate the best output power and compare the real o/p of the working group. The fault generated is used to check the current edge. In a related version provided by WG, the output power is deliberate, and the object rotor speed for OP generation is obtained according to the WG characteristic curve of the rotor speed and the optimal power.

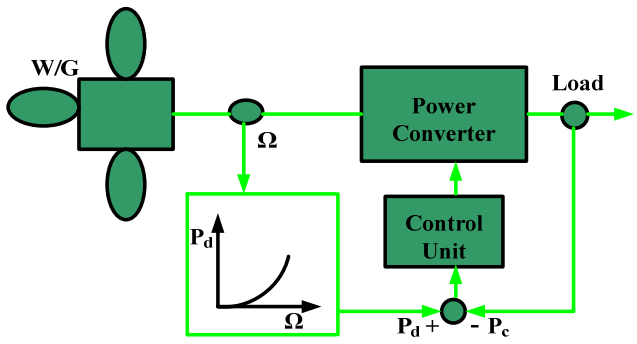

Fig.2. CSB on RPM measurements [23]

The control system based (CSB) on wind speed measurement is shown in Fig.3. Measure the wind speed and calculate the rotor speed required to generate maximum power. The error is generated and is used to control the power interface by comparing the measured speed of the rotor with the calculated optimal rotor speed.

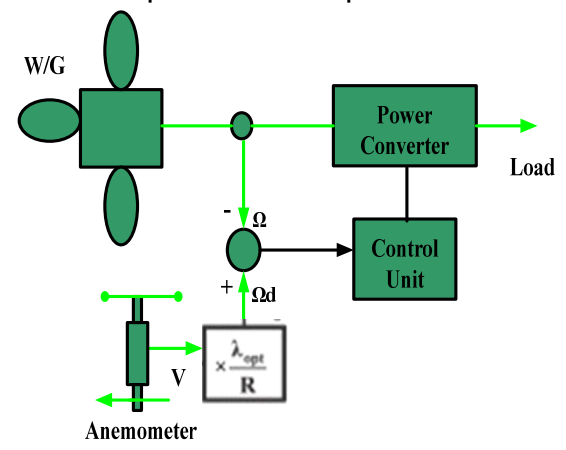

Fig.3. CBS on wind speed measurements [19]

The implementation of an FLC-based control system that transfers maximum power from a WECS to a supply network is shown in $[24,25]$. The controller is based on multimode approaches with optimal power compared to the WG wind velocity feature.

The goal of this paper is to present:

- A comprehensive survey of WECs, as well as different kinds of existing WECs;

- Several MPPT control methods and

- Comparison of distinct WECs and MPPT techniques.

The purpose of this article is to conduct a comprehensive review of WEC, including the current different types of WEC, multiple MPPT control methods, and a comparison of different 
WEC and MPPT methods. The latest development of WEC has introduced new generators and new system topologies.

The paper is distributed into 4 sections. In Section 1, the RE has been discussed. In section 2, the methodology and different methods have been described. Discussion about MPPT techniques with others has been discussed in section 3. Finally, the literature-based analysis concluded in section 4 .

\section{METHODOLOGY}

The WECS studies have the arrangement as shown in Fig.4. The structure contains WT, a large amount of modular PM Generator [26,27], and a modular rectifier system [28] as well as controllable power electronic inverters $[29,30]$.

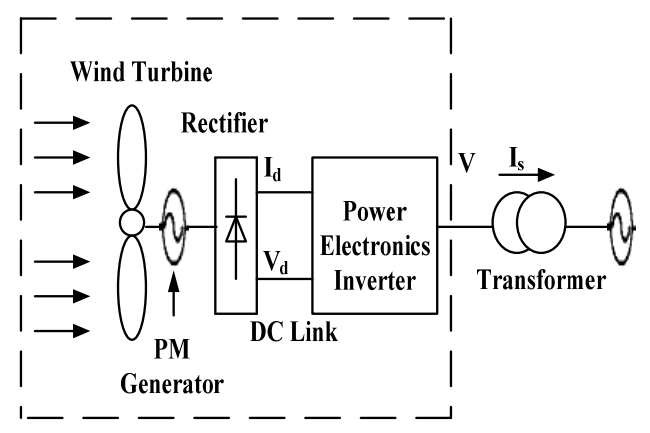

Fig.4. Schematic of WECS [26]

Due to changes in wind speed, variable speed wind turbines (VSWTS) are the most important in wind energy conversion systems (WECS) because they can efficiently use WE [31,32]. In modern wind farms, dual-fed induction generators (DFIG) and VSWT-based permanent magnet synchronous generators (PMSG) are the most popular. Fig.5a illustrates the basic arrangement of WECS. PMSG can improve the gearbox therefore; they can solve all taste problems. The WE produced by the WT is sent to the generator. The speed of PMSG is controlled using a PWM sensor. The o/p power of PMSG is provided to the grid throughout the generator and grid side inverter. The schematic figure of the WECS system based on DFIG is presented in Fig.5b. The DFIG stator is directly linked to the belt, and the PVWM inverter controls the rotor of three continuous voltage sources, which are connected to the belt on the other side. There are various materials regarding the modeling and control strategy of WECS switches based on PMSG and DFIG. The power homogenization method can be used to generate uniform power output of all types of VSWT [33-36].

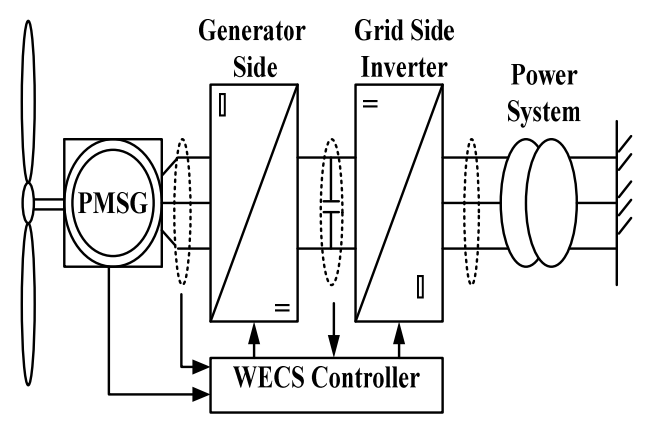

a) PMSG based WTfig

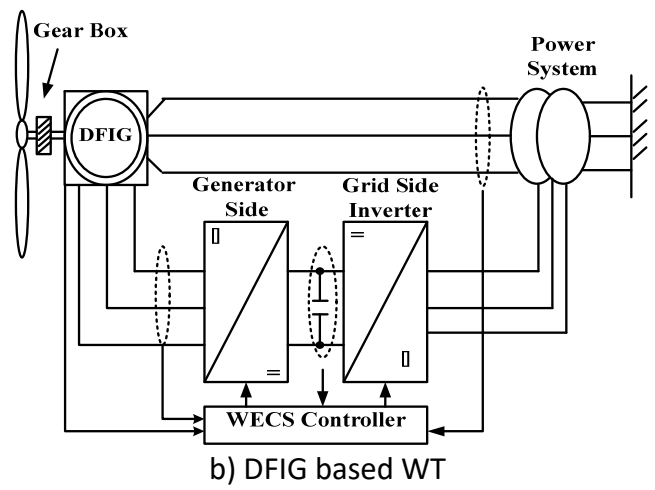

Fig.5. WECs [31]

\subsection{MPPT Techniques}

\subsubsection{Power Signal Feedback (PSF) Based MPPT Technique}

PSF technology depends on algorithms for power sensor feedback without power signals and offers many advantages over others using MPPT. Basic training of optimal curves is required to determine optimal efficiency through this MPPT method [37-40]. The diagram of the basic PSF block is shown in Fig.6. The PSF method uses a reference force, which is the maximum force at a given wind speed. This has caused problems because prior knowledge of WT properties and wind speed measurements is required.

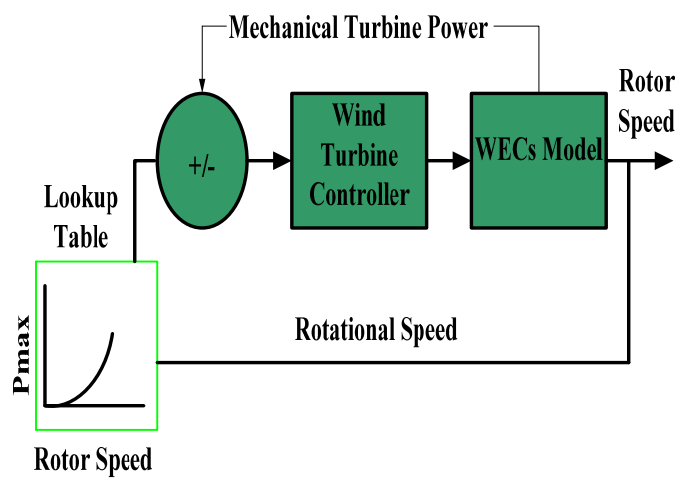

Fig.6. Basic block diagram of PSF [37] 


\subsubsection{Tip Speed Ratio Based MPPT Technique}

Tip speed ratio (TSR) based MPPT technique is an easy technique as wind movement is predicted straight and continuously experimentally can be considered. The best TSR for a specific WT is determined independently of the wind speed. However, Fig.7 illustrates, the wind speed is measured to get the optimal rotor speed above the optimal end speed level. The prediction method is based on the repulsion of the auxiliary vector, with the aid of obtaining the approximate wind speed with the power and speed of the WT.

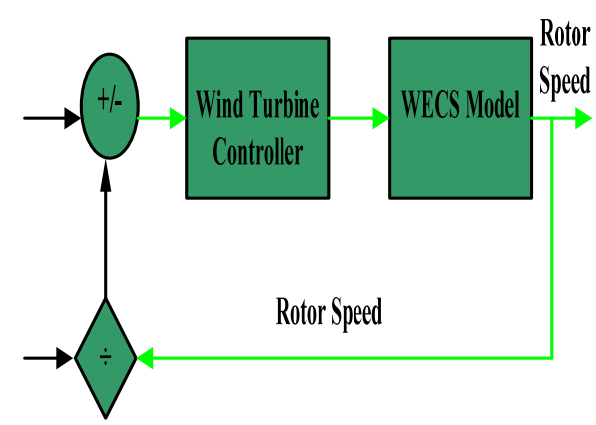

Fig.7. Basic block illustration of TSR [41-42]

TSR control suggests the best efficiency with quick response and high effectiveness. The exact wind speed cannot be measured. The perfect anemometer is costly and raises the price in the system [40].

TSR can be expressed as follows;

$$
T S R=\lambda=\frac{\omega r}{V}
$$

where,

- $\omega=$ rotor tip speed,

- $\quad V=$ wind speed and

- $r=$ rotor radius [43].

\subsubsection{Optimal Torque Control (OTC) Based MPPT Technique}

This technique is illustrated in Fig.8. The basic principle of this technology is to adjust the torque of the power generator from the desired wind turbine speed (WTS) to the optimal energy reference torque.

Turbine performance can be expected as a function of the final speed and the ratio of TS [4446]. Therefore, the optimal torque equation can be written to get wind speed. We know that:

$$
\begin{aligned}
& P_{t_{-} \text {opt }}=\frac{1}{2 \lambda_{c}^{3}} \Pi \rho R^{5} \omega_{t}^{3} C_{p_{-} \text {opt }} ; T_{t_{-} \text {opt }}=P_{t_{-} \text {opt }} \frac{1}{\omega_{t}} \\
& T_{t_{-} \text {opt }}=\frac{1}{2 \lambda_{c}^{3}} \Pi \rho R^{5} C_{p_{-} \text {opt }} \omega_{t}^{2}=k_{\text {opt }} \omega_{t}^{2} \\
& k_{\text {opt }}=\frac{1}{2 \lambda_{c}^{3}} \Pi \rho R^{5} \omega_{t}^{2} C_{p_{-} \text {opt }}
\end{aligned}
$$

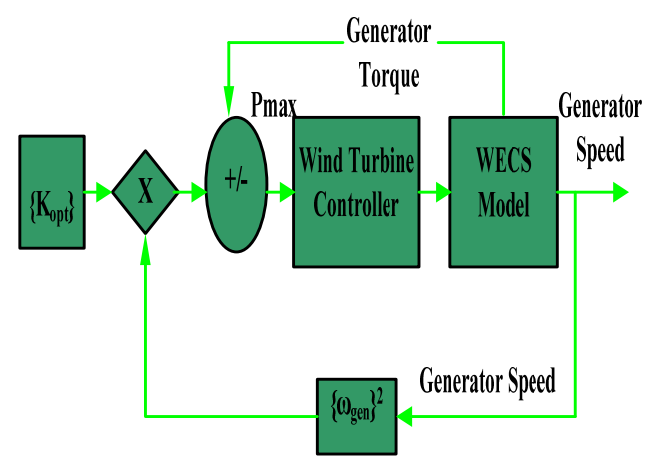

Fig.8. OT control method

Where equation 2 is the OT curve analytical expression and can be utilized as mechanical torque control. The authors in [47] report that there is not much difference between the MPPT controller and the OTC-based MPPT controller in terms of power and complexity. The OT control method is efficient, fast to operate, and simple to plan. OTC does not smoothly forecast WS, so its efficiency is slower than TSR [48].

\subsubsection{FLC Based MPPT Technique}

To adopt fast response and low oscillation near MPP, FLC is used for the MPPT algorithm without the need for precise WECS mathematical modelling. However, designers still need better knowledge to determine the appropriate surface error, membership function level, and the choice of the underlying base layer with large storage space requirements [49-53].

Aerodynamic torque monitors and speed are used as input (i/p) values of FLC-based MPPT shown in Fig.9. The other two input parameters and $\Delta T a$ and $\Delta \omega m$ can limit the difference in speed and torque. These $i / p$ parameters are changed into a pre-defined devoted function and sent to the FLC. FLC uses empirical rules and interference elimination methods to calculate the output parameter, which is the output torque. 


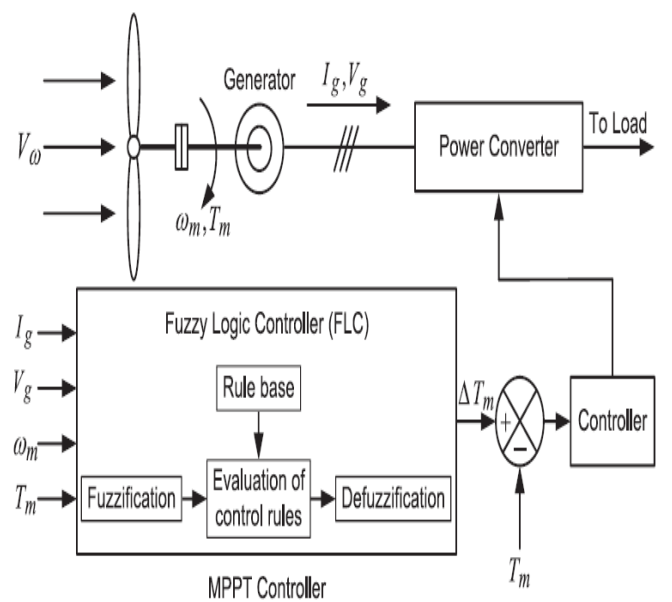

Fig.9. FLC-based MPPT Technique of WECS $[50,54]$

\section{DISCUSSION AND COMPARATIVE ANALYSIS}

The proposed technology is compared with the three traditional MPPT techniques that have been discussed in Table 1 . The presented MPPT technology has the key supremacy of ordinary MPPT techniques. Anemometer has not required distinct a TSR method due to expensive and not being used in small WECS. Speedy tracking performance is like ORB control but does not need prior system knowledge. In addition, it can be updated online by running more $P \& O$ like training methods without switching MPPT.
Through the above study of distinct MPPT technologies, a comparison Table 2 is developed in terms of complication, speed convergence, sensor required for wind speed, performance, and memory requirement. The key goal of the MPPT technique is to follow the optimal power point of a VSWT. Selecting the right MPPT technology is a difficult job. In comparison, algorithms based on PSF, OT, and TSR are uncomplicated and quick, but they increase the confined mechanical wind energy as a substitute for electrical $o / p$ energy. The tip speed ratio controller has high efficiency, quick response of speed, and good performance. Due to storms and turbulence, an accurate anemometer is required, which is expensive and adds extra cost to the system, especially for small-scale WECS.

Since the wind speed near the turbine is different from the speed of the free flow, the practical application of this algorithm is very difficult. Though, it does not exactly measure the speed of wind (WS), so the change in WS cannot be immediately and extensively reflected on the indicating torque, which builds the efficiency of this technique lower than that of the TSR technique. OT and PSF techniques are roughly the same in terms of performance and complication. This technique affords WECS with powerful and economical control of MPPT.

Table 1. Comparison with conventional MPPT Techniques

\begin{tabular}{|l|c|c|c|c|c|}
\hline Techniques & $\begin{array}{c}\text { Oscillation at } \\
\text { MPP }\end{array}$ & $\begin{array}{c}\text { Pre knowledge } \\
\text { System }\end{array}$ & Anemometer & $\begin{array}{c}\text { Speed } \\
\text { Tracking }\end{array}$ & $\begin{array}{c}\text { Updating } \\
\text { Online }\end{array}$ \\
\hline P\&O & Yes & Not Essential & No & Slow & Yes \\
\hline $\begin{array}{l}\text { Optimum } \\
\text { Relationship } \\
\text { Based (ORB) }\end{array}$ & No & Essential & No & Fast & No \\
\hline Tip speed ratio & No & Essential & Yes & Fast & No \\
\hline Proposed Method & No & Not Essential & No & Fast & Yes \\
\hline
\end{tabular}

Table 2 Comparative analysis of distinict MPPT Techniques

\begin{tabular}{|c|c|c|c|c|c|c|c|}
\hline Techniques & $\begin{array}{c}\text { Speed } \\
\text { Convergence }\end{array}$ & Complication & $\begin{array}{c}\text { Online } \\
\text { updating }\end{array}$ & $\begin{array}{c}\text { Sensor } \\
\text { Required for } \\
\text { Wind speed }\end{array}$ & $\begin{array}{l}\text { Requirement } \\
\text { of Memory }\end{array}$ & $\begin{array}{c}\text { Performance } \\
\text { under } \\
\text { flexible wind } \\
\text { environment }\end{array}$ & Ref. \\
\hline TSR & Quick & Uncomplicated & $x$ & $\checkmark$ & $x$ & Moderate & [49] \\
\hline OT & Quick & Uncomplicated & $x$ & $\times$ & $x$ & Moderate & [50] \\
\hline PSF & Quick & Uncomplicated & $x$ & $\checkmark$ & $\checkmark$ & Moderate & [55] \\
\hline FLC & Normal & Huge & $\checkmark$ & Depënds & $\checkmark$ & Very-Good & [56] \\
\hline NN-based & Normal & Huge & $\checkmark$ & Dëpends & $\checkmark$ & Very-Good & [57] \\
\hline MVPO & Slow & Huge & $\checkmark$ & $x$ & $x$ & Good & [58] \\
\hline ORB & Normal & Uncomplicated & $x$ & $x$ & $x$ & Moderatë & [59] \\
\hline INC & Slow & Uncomplicated & $\checkmark$ & $\times$ & $x$ & Moderate & [60] \\
\hline $\mathrm{P} \& O$ & Quick & Uncomplicated & $\checkmark$ & Depends & $x$ & Very Good & [61] \\
\hline
\end{tabular}




\section{CONCLUSION}

This article analyzes the MPPT techniques for WECS based on a review of the literature. During the training mode, the technology quickly improves the optimum amount of DC output voltage and DC current. It is recommended to use advanced $P \& O$ methods to abolish the influence of wind conditions. Then, manage the system based on these good relationships. The suggested MPPT technology does not need anemometer / prior system knowledge, but can accurately and quickly respond to wind speed. In addition, the proposed technology can be enhancing to include systems with unusual topologies.

\begin{tabular}{|llll|}
\hline Nomenclature & & & \\
\hline Abbreviation & wind power generation & FLC & fuzzy logic controller \\
WPG & renewable energy & VSWTS & variable speed wind turbine \\
RE & wind energy & DFIG & dual fed induction generator \\
WE & maximum power point tracking & PMSG & $\begin{array}{l}\text { permanent magnet } \\
\text { MPPT }\end{array}$ \\
WECS & wind energy conversion systems & & synchronous generator \\
WPG & wind power generation & PWM & pulse width modulation \\
WT & sustainable energy & PSF & power signal feedback \\
SE & renewable energy source & TSR & tip speed ratio \\
RES & OT & optimal torque \\
WG & wind generation & TS & turbine speed \\
CSB & control system based & ORB & optimum relationship based \\
& & & \\
\hline
\end{tabular}

\section{REFERENCES}

[1] M.A. Koondhar, M.I. Jamali, A.S. Channa, I.A. Laghari, Partial Shading Effect on the Performance of PV Panel and its Different Circuit Topologies Based Mitigation Techniques: A Review. International Journal of Advanced Research in Engineering and Technology, 12 (4), 2021: 15-23.

https://doi.org/10.34218/IJARET.12.4.2021. $\underline{003}$

[2] S.R. Bull, Renewable energy today and tomorrow. Proceedings of the IEEE, 89 (8), 2001: 1216-1226.

https://doi.org/10.1109/5.940290

[3] Z. Haoran, B. Kaiming, H. Hong, A state-ofthe-art review on the vibration mitigation of wind turbines. Renewable and Sustainable Energy Reviews, 121, 2020: 109710.

https://doi.org/10.1016/j.rser.2020.109710

[4] A.M. Update, Global wind report. Global Wind Energy Council, 2017.

[5] M.A. Abdullah, A.H. Yatim, C.W. Tan, R. Saidur, A review of maximum power point tracking algorithms for wind energy systems. Renewable and sustainable energy reviews, 16 (5), 2012: 3220-3227.

https://doi.org/10.1016/j.rser.2012.02.016
[6] M.A. Abdullah, A.H. Yatim, C.W. Tan, A study of maximum power point tracking algorithms for wind energy system. In IEEE Conference on Clean Energy and Technology (CET) 2011: 321-326. https://doi.org/10.1109/CET.2011.6041484

[7] R. Saidur, M.R. Islam, N.A. Rahim, K.H. Solangi, A review on global wind energy policy. Renewable and sustainable energy reviews, 14 (7), 2010: 1744-1762. https://doi.org/10.1016/j.rser.2010.03.007

[8] D. Lamsal, V. Sreeram, Y. Mishra, D. Kumar, Output power smoothing control approaches for wind and photovoltaic generation systems: A review. Renewable and Sustainable Energy Reviews, 113, 2019: 109245.

https://doi.org/10.1016/j.rser.2019.109245

[9] M.A. Chowdhury, N. Hosseinzadeh, W.X. Shen, Smoothing wind power fluctuations by fuzzy logic pitch angle controller. Renewable Energy, 38 (1), 2012: 224-233.

https://doi.org/10.1016/j.renene.2011.07.034

[10] R.M. Kamel, A. Chaouachi, K. Nagasaka, RETRACTED: Wind power smoothing using fuzzy logic pitch controller and energy capacitor system for improvement micro- 
grid performance in islanding mode. Energy, 35, 2010: 2119-2129.

https://doi.org/10.1016/j.energy.2010.01.030

[11] M. Dreidy, H. Mokhlis, S. Mekhilef, Inertia response and frequency control techniques for renewable energy sources: A review. Renewable and sustainable energy reviews, 69, 2017: 144-155.

http://dx.doi.org/10.1016/j.rser.2016.11.170

[12] J. Dong, G. Xue, M. Dong, X. Xu, Energysaving power generation dispatching in China: Regulations, pilot projects and policy recommendations - A review. Renewable and Sustainable Energy Reviews, 43, 2015: 1285-1300.

https://doi.org/10.1016/j.rser.2014.11.037

[13] R. Saidur, N.A. Rahim, M.R. Islam, K.H. Solangi, Environmental impact of wind energy. Renewable and sustainable energy review, 15 (5), 2011: 2423-2430.

https://doi.org/10.1016/j.rser.2011.02.024

[14] C. Breidenich, D. Magraw, A. Rowley, J.W. Rubin, The Kyoto protocol to the United Nations framework convention on climate change. American Journal of International Law, 92 (2), 1998: 315-331.

[15] D. Lashof, S. Yeh, S. Carter, D. Doniger, D. Murrow, L. Johnson, Cleaner and cheaper: Using the clean air act to sharply reduce carbon pollution from existing power plants, delivering health, environmental, and economic benefits. Natural Resources Defence Council (NRDC), 2014: 1-12.

[16] Global Status Report, REN21 Secretariat, Paris, France. InTech. Rep, 2017: 91-93.

[17] L. Lu, H. Yang, J. Burnett, Investigation on wind power potential on Hong Kong islands - an analysis of wind power and wind turbine characteristics. Renewable Energy, 27 (1), 2002: 1-12.

https://doi.org/10.1016/S09601481(01)00164-1

[18] M.A. Elhadidy, S.M. Shaahid, Parametric study of hybrid (wind+ solar+ diesel) power generating systems. Renewable energy, 21 (2), 2000: 129-139.

https://doi.org/10.1016/S09601481(00)00040-9

[19] E. Koutroulis, K. Kalaitzakis, Design of a maximum power tracking system for windenergy-conversion applications. IEEE transactions on industrial electronics UK, 53(2), April 3, 2006, 486-494.

https://doi.org/10.1109/TIE.2006.870658

[20] L.L. Freris, Wind Energy Conversion Systems. Englewood Cliffs, NJ: Prentice-Hall, 1990; 182-184.

[21] V. Valtchev, A. Van den Bossche, J. Ghijselen, J. Melkebeek, Autonomous renewable energy conversion system. Renewable energy, 19 (1-2), 2000: 259-275.

https://doi.org/10.1016/S09601481(99)00040-3

[22] E. Muljadi, C.P. Butterfield. Pitch-controlled variable-speed wind turbine generation. IEEE transactions on Industry Applications USA, 37 (1), January 2, 2001, 240-246.

https://doi.org/10.1109/28.903156

[23] A.M. De Broe, S. Drouilhet, V. Gevorgian, A peak power tracker for small wind turbines in battery charging applications. IEEE Transactions on energy conversion Italy, 14 (4), December 5, 1999, 1630-1635. https://doi.org/10.1109/60.815116

[24] R.M. Hilloowala, A.M. Sharaf, A rule-based fuzzy logic controller for a PWM inverter in a stand alone wind energy conversion scheme. IEEE Transactions on Industry Applications USA, 32 (1), 1996: 57-65. https://doi.org/10.1109/28.485813

[25] N. Mohan, T.M. Undeland, W.P. Robbins, Power electronics: converters, applications, and design. John wiley \& sons, 2003.

[26] Z. Chen, E. Spooner, Grid power quality with variable speed wind turbines. IEEE Transactions on energy conversion, 16 (2), 2001: 148-154.

https://doi.org/10.1109/60.921466

[27] E. Spooner, A.C. Williamson, G. Catto, Modular design of permanent-magnet generators for wind turbines. IEEE Proceedings-Electric Power Applications, 143 (5), 1996: 388-395.

[28] Z. Chen, and E. Spooner, A modular, permanent-magnet generator for variable speed wind turbines. Seventh International Conference on Electrical Machines and Drives, September 11-13, 1995, Durham, UK, 453-457.

https://doi.org/10.1049/cp:19950913

[29] Z. Chen, E. Spooner, Grid interface for renewable energy sources. In $2^{\text {nd }}$ 
International Power electronics and motion control conference, November 3-6, 1997, Hangzhou, China, 256-261.

[30] Z. Chen, E. Spooner, Grid interface options for variable-speed, permanent-magnet generators. IEEE Proceedings-Electric Power Applications, 145 (4), 1998, 273-283.

https://doi.org/10.1049/ip-epa:19981981

A.M. Howlader, N. Urasaki, A. Yona, T. Senjyu, A.Y. Saber, A review of output power smoothing methods for wind energy conversion systems. Renewable and Sustainable Energy Reviews, 26, 2013: 135146.

https://doi.org/10.1016/j.rser.2013.05.028

[31] P.W. Carlin, A.S. Laxson, E.B. Muljadi, The history and state of the art of variable-speed wind turbine technology. Wind Energy: An International Journal for Progress and Applications in Wind Power Conversion Technology, 6 (2), 2003: 129-159.

https://doi.org/10.1002/we.77

[32] A. Uehara, A. Pratap, T. Goya, T. Senjyu, A. Yona, N. Urasaki, T. Funabashi, A coordinated control method to smooth wind power fluctuations of a PMSG-based WECS. IEEE Transactions on energy conversion, 26 (2), 2011: 550-558.

https://doi.org/10.1109/TEC.2011.2107912

[33] H.W. Kim, S.S. Kim, H.S. Ko, Modeling and control of PMSG-based variable-speed wind turbine. Electric Power Systems Research, 80 (1), 2010: 46-52.

https://doi.org/10.1016/j.epsr.2009.08.003

[34] M. Rahimi, M. Parniani, Coordinated control approaches for low-voltage ride-through enhancement in wind turbines with doubly fed induction generators. IEEE Transactions on Energy Conversion, 25 (3), 2010: 873-883. https://doi.org/10.1109/TEC.2010.2050485

[35] E.B. Muhando, T. Senjyu, A. Uehara, T. Funabashi, Gain-scheduled $\mathrm{H} \infty$ control for WECS via LMI techniques and parametrically dependent feedback part I: model development fundamentals. IEEE Transaction on Industrial Electronics, 58 (1), 2011: 48-56.

\section{https://doi.org/10.1109/TIE.2010.2045317}

[36] M. Hussain, M.H. Baloch, A.H. Memon, N.K. Pathan, Maximum power tracking system based on power electronic topology for wind energy conversion system applications.
Engineering, Technology \& Applied Science Research, 8 (5), 2018: 3392-3397.

https://doi.org/10.48084/etasr.2251

[37] C.P. Van Dam, D.E. Berg, S.J. Johnson, Active load control techniques for wind turbines. Sandia National Laboratories, 2008.

[38] S.P. LakshmanRao, C.P. Kurian, B.K. Singh, V.A. Jyothi, Simulation and control of DC/DC converter for MPPT based hybrid PV/Wind power system. International journal of renewable energy research, 4 (3), 2014: 801809.

[39] S.S. Mali, B.E. Kushare, MPPT algorithms: Extracting maximum power from wind turbines. International Journal of Innovative Research in Electrical, Electronics, Instrumentation and Control Engineering, 1 (5), 2013: 199-202.

[40] W.M. Lin, C.M. Hong, F.S. Cheng, Fuzzy neural network output maximization control for sensorless wind energy conversion system. Energy, 35 (2), 2010: 592-601.

https://doi.org/10.1016/j.energy.2009.10.030

[41] A.G. Abo-Khalil, D.C. Lee, MPPT control of wind generation systems based on estimated wind speed using SVR. IEEE transactions on Industrial Electronics, 55 (3), 2008: 1489-1490.

https://doi.org/10.1109/TIE.2007.907672

[42] M. Ragheb, A.M. Ragheb. Wind turbines theory the betz equation and optimal rotor tip speed ratio. Fundamental and advanced topics in wind power, 1 (1), 2011: 19-38. https://doi.org/10.5772/21398

[43] S. Morimoto, H. Nakayama, M. Sanada, Y. Takeda, Sensorless output maximization control for variable-speed wind generation system using IPMSG. IEEE Transactions on industry applications, 41 (1), 2005: 60-67. https://doi.org/10.1109/TIA.2004.841159

[44] M. Kesraoui, N. Korichi, A. Belkadi, Maximum power point tracker of wind energy conversion system. Renewable energy, 36 (10), 2011: 2655-2662.

https://doi.org/10.1016/i.renene.2010.04.0 28

[45] M. Pucci, M. Cirrincione, Neural MPPT control of wind generators with induction machines without speed sensors. IEEE Transactions on Industrial Electronics, 58 (1), 2010: 37-47. 
https://doi.org/10.1109/TIE.2010.2043043

[46] S.M. Kazmi, H. Goto, H.J. Guo, O. Ichinokura, A novel algorithm for fast and efficient speed-sensorless maximum power point tracking in wind energy conversion systems. IEEE transactions on industrial electronics, 58 (1), 2010: 29-36. https://doi.org/10.1109/TIE.2010.2044732

[47] M. Kesraoui, N. Korichi, A. Belkadi, Maximum power point tracker of wind energy conversion system. Renewable energy, 36 (10), 2011: 2655-2662.

https://doi.org/10.1016/j.renene.2010.04.0 28

[48] H.H. Mousa, A.R. Youssef, E.E. Mohamed, State of the art perturb and observe MPPT algorithms based wind energy conversion systems: A technology review. International Journal of Electrical Power \& Energy Systems, 126, 2021: 106598.

https://doi.org/10.1016/j.ijepes.2020.106598

[49] D. Kumar, K. Chatterjee, A review of conventional and advanced MPPT algorithms for wind energy systems. Renewable and sustainable energy reviews, 55, 2016: 957970.

http://dx.doi.org/10.1016/i.rser.2015.11.013

[50] V. Galdi, A. Piccolo, P. Siano, Designing an adaptive fuzzy controller for maximum wind energy extraction. IEEE Transactions on Energy Conversion, 23 (2), 2008: 559-569. http://dx.doi.org/10.1109/TEC.2007.914164

[51] J. Hui, A. Bakhshai, P.K. Jain, An adaptive approximation method for maximum power point tracking (MPPT) in wind energy systems. In 2011 IEEE Energy Conversion Congress and Exposition, September 17-22, 2011, Phoenix, AZ, USA, 2664-2669. http://dx.doi.org/10.1109/ECCE.2011.60641 25

[52] C. Viveiros, R. Melício, J.M. Igreja, V.M.F. Mendes, Supervisory control of a variable speed wind turbine with doubly fed induction generator. Energy Rep, 1, 2015, 89-95.

https://doi.org/10.1016/j.egyr.2015.03.001

[53] B. Neammanee, K. Krajangpan, S. Sirisumrannukul, S. Chatratana, Maximum peak power tracking-based control algorithms with stall regulation for optimal wind energy capture. IEEE Power Conversion Conference Nagoya, Japan, 128 (4), 2007: 411-417.

https://doi.org/10.1109/PCCON.2007.373151

[54] S. M. Tripathi, A. N. Tiwari, D. Singh, Gridintegrated permanent magnet synchronous generator based wind energy conversion systems: A technology review. Renewable and Sustainable Energy Reviews, 51, 2015: 1288-1305.

https://doi.org/10.1016/j.rser.2015.06.060

[55] S. Musunuri, H.L. Ginn, Comprehensive review of wind energy maximum power extraction algorithms. In IEEE power and energy society general meeting, July 24-28, 2011, Detroit, MI, USA, 1-8.

https://doi.org/10.1109/PES.2011.6039023

[56] R. Tiwari, N.R. Babu, Recent developments of control strategies for wind energy conversion system. Renewable and Sustainable Energy Reviews, 66, 2016: 268285.

https://doi.org/10.1016/j.rser.2016.08.005

[57] H. Fathabadi, Maximum mechanical power extraction from wind turbines using novel proposed high accuracy single-sensor-based maximum power point tracking technique. Energy, 113, 2016: 1219-1230.

https://doi.org/10.1016/j.energy.2016.07.081

[58] K. N. Yu, C. K. Liao, Applying novel fractional order incremental conductance algorithm to design and study the maximum power tracking of small wind power systems. Journal of applied research and technology, 13 (2), 2015: 238-244.

[59] Z. M. Dalala, Z. U. Zahid, W. Yu, Y. Cho, Y., J. S. Lai, Design and analysis of an MPPT technique for small-scale wind energy conversion systems. IEEE transactions on energy conversion, 28 (3), 2013: 756-767. https://doi.org/10.1109/TEC.2013.2259627

[60] A. Harrag, S. Messalti, Variable step size modified P\&O MPPT algorithm using GAbased hybrid offline/online PID controller. Renewable and Sustainable Energy Reviews, 49, 2015: 1247-1260.

https://doi.org/10.1016/j.rser.2015.05.003 